medRxiv preprint doi: https://doi.org/10.1101/2021.01.22.20249050; this version posted January 26, 2021. The copyright holder for this preprint (which was not certified by peer review) is the author/funder, who has granted medRxiv a license to display the preprint in perpetuity. All rights reserved. No reuse allowed without permission.

\title{
A High-throughput Microsphere-based Immunoassay of Anti-SARS-CoV-2 IgM Testing for COVID-19 Diagnostics
}

Dayu Zhang ${ }^{1}$, Tianyang $\mathrm{Xu}^{1}$, Eric $\mathrm{Chu}^{1}$, Aiguo Zhang ${ }^{1}$, Jinwei Du ${ }^{1 *}$ and Michael Y. Sha ${ }^{1 *}$

${ }^{1}$ DiaCarta Inc, 2600 Hilltop Dr. Richmond, CA 94806

Corresponding authors: jdu@diacarta.com and msha@diacarta.com

\section{Running Title: High throughput Anti-SARS-CoV-2 IgM Detection}


medRxiv preprint doi: https://doi.org/10.1101/2021.01.22.20249050; this version posted January 26, 2021. The copyright holder for this preprint (which was not certified by peer review) is the author/funder, who has granted medRxiv a license to display the preprint in perpetuity.

All rights reserved. No reuse allowed without permission.

\begin{abstract}
:
The pandemic of novel coronavirus disease COVID-19 is rapidly expanding across the world. A positive result of antibody tests suggests that the individual has potentially been exposed to SARS-CoV-2, thus allowing to identify asymptomatic infections and determine the seroprevalence in a given population. The aim of this study was to evaluate the performances of a newly developed high throughput immunoassay for anti-SARS-CoV-2 IgM antibody detection on the Luminex MAGPIX platform. Clinical agreement studies were performed in 42 COVID-19 patient serum samples and 162 negative donor serum/plasma samples. Positive percent agreement (PPA) was 42.86\% (95\% CI: 9.90\% to 81.59\%), $71.43 \%$ (95\% CI: $29.04 \%$ to $96.33 \%$ ), and $28.57 \%$ (95\% CI: $13.22 \%$ to $48.67 \%$ ) for samples collected on 0-7 days, $8-14$ days, and 2-8 weeks from symptom onset, respectively. Negative Percent Agreement (NPA) was 97.53\% (95\% CI: $93.80 \%$ to $99.32 \%$ ). There was no cross-reactivity with the SARS-CoV-2 IgG antibody. Hemoglobin $(200 \mathrm{mg} / \mathrm{dL})$, bilirubin $(2 \mathrm{mg} / \mathrm{dL})$, triglyceride $(250 \mathrm{mg} / \mathrm{dL})$ and EDTA $(10 \mathrm{mM})$ showed no significant interfering effect on this assay. In conclusion, an anti-SARS-CoV-2 IgM antibody assay with high sensitivity and specificity has been developed. With the high throughput, this assay will speed up the anti-SARS-CoV-2 IgM testing.
\end{abstract}

KEYWORDS: COVID-19; SARS-CoV-2; IgM Test; Immunoassay. 
medRxiv preprint doi: https://doi.org/10.1101/2021.01.22.20249050; this version posted January 26, 2021. The copyright holder for this preprint (which was not certified by peer review) is the author/funder, who has granted medRxiv a license to display the preprint in perpetuity.

All rights reserved. No reuse allowed without permission.

\section{Introduction}

The SARS-CoV-2 virus has been identified as the cause of a respiratory illness outbreak in Wuhan, China in late 2019 and has since evolved into a global pandemic, COVID-19. As of early November 2020, 47 million people have contracted the virus and more than 1 million people have died. Nucleic acid amplification testing methods such as PCR have been the gold standard for COVID-19 detection during the early phase of infection. However, there is an increasing demand for antibody detection for determining the seroprevalence of COVID-19 in the general population. The shortage of swabs and nucleic acid detection kits in certain areas have also evoked the appreciation of serology tests. The SARSCoV-2 serostatus of asymptomatic patients or patients with symptoms appearing late into the infection is of particular interest. The government and the media have been promoting positive antibody tests as an alternative or additional screening standard for individuals returning to work. A recent study demonstrated that both IgM and IgG antibodies were detectable 5 days after onset in all 39 patients with SARS-CoV-2 infection (3), and the median day of seroconversion for both $\operatorname{IgG}$ and $\operatorname{IgM}$ was 13 days post symptom onset (4). The presence of IgM antibodies can indicate an active or recent infection while the presence of IgG antibodies usually signals past infection. Ultimately, serological testing can help detect cases of SARS-CoV-2 for which PCR testing resulted in false negatives, identify asymptomatic infections, confirm results for clinically suspicious cases, and help guide return-to-work or travelling decisions (5). Herein, we reported the performance evaluation of the QuantiVirus ${ }^{\mathrm{TM}}$ anti-SARS-CoV-2 IgM test which is a two-step immunoassay using Luminex platform to detect anti-SARS-CoV-2 spike protein 1 (S1) receptor-binding domain (RBD) IgM antibody in human serum or plasma specimens. Validation of the test was conducted using COVID-19 negative and positive samples on MAGPIX ${ }^{\circledR}$ instruments. The test takes approximately 3 hours per run with a 96-well plate capable of testing 92 patient samples, enabling a streamlined workflow for high-throughput COVID-19 antibody testing. 
medRxiv preprint doi: https://doi.org/10.1101/2021.01.22.20249050; this version posted January 26, 2021. The copyright holder for this preprint (which was not certified by peer review) is the author/funder, who has granted medRxiv a license to display the preprint in perpetuity.

All rights reserved. No reuse allowed without permission.

\section{Methods and Materials}

\subsection{Instrumentation}

According to the guidance issued by Centers for Disease Control (CDC) and the World Health Organization (WHO), all studies were conducted in a Biosafety Level 2 (BSL-2) cabinet when handling COVID-19 patient samples. The microplate shaker (PlexBio Co, Taiwan) was used for microplate shaking and incubation. Data acquisition was performed on Luminex MAGPIX ${ }^{\circledR}$ instruments (Luminex, Austin, TX).

\subsection{Reagents and patient samples}

The recombinant SARS-CoV-2 Spike protein 1 (RBD)-His was produced from HEK293 suspension cells (Innovative Research, Inc, MI). Anti-SARS-CoV-2 Spike RBD monoclonal antibody (IgM isotype) was purchased from Creative Diagnostics (Shirley, NY). PE conjugated anti-human IgM antibody was purchased from BioLegend (San Diego, CA). MagPlex Microsphere and xMAP ${ }^{\circledR}$ Antibody Coupling (AbC) kit were purchased from Luminex (Austin, TX). Hemoglobin (human), bilirubin, triglyceride and EDTA were purchased from Sigma-Aldrich (St. Louis, MO). BlockAid ${ }^{\text {TM }}$ Blocking Solution was purchased from ThermoFisher Scientific (Waltham, MA). 96-well microplates (flat bottom, clear) were purchased from Greiner bio-one (Monroe, NC).

Healthy donor EDTA K2 plasma samples were purchased from Golden West Biosolutions (Temecula, CA) and healthy donor serum samples were purchased from Innovative Research, LLC (Plymouth, MN). COVID-19 patient serum samples were acquired from ProMedDx (Norton, MA).

\subsection{Assay procedure}

Principle of the assay is shown in Figure 1. Recombinant spike protein 1 (S1) RBD was covalently coupled to the surface of MagPlex ${ }^{\circledR}$ Microspheres (magnetic beads) via a carbodiimide linkage using $\mathrm{xMAP}^{\circledR}$ Antibody Coupling (AbC) kit. First, $3 \mu \mathrm{L}$ of S1 RBD protein coated magnetic beads, $87 \mu \mathrm{L}$ of BlockAid $^{\mathrm{TM}}$ Blocking Solution and $10 \mu \mathrm{L}$ of serum or plasma samples were loaded to 96-well plate and incubated at room temperature for 1 hour with shaking at 600rpm. The IgM antibodies present in human specimens against S1 RBD protein (the antigen) will bind to the coated magnetic beads. After washing, 
medRxiv preprint doi: https://doi.org/10.1101/2021.01.22.20249050; this version posted January 26, 2021. The copyright holder for this preprint (which was not certified by peer review) is the author/funder, who has granted medRxiv a license to display the preprint in perpetuity.

All rights reserved. No reuse allowed without permission.

PE conjugated anti-human $\operatorname{IgM}$ antibody was added to the reaction mixture and incubated at room temperature for 30 minutes with shaking at 600rpm. After washing, data acquisition was performed on MAGPIX $^{\circledR}$ instrument for Median Fluorescence Intensity (MFI). Interpretation of the testing results was performed by calculating the ratio between the MFI of each sample and the average MFI of two blank wells. The sample will be interpreted as positive when the ratio is $\geq 45$; otherwise, the sample will be considered negative for Anti-SARS-CoV-2 IgM antibody.

\subsection{Performance evaluation}

To evaluate the clinical performance of the QuantiVirus ${ }^{\mathrm{TM}}$ Anti-SARS-CoV-2 IgM Test, 162 COVID-19 negative samples and 42 COVID-19 positive samples were tested and evaluated for NPA and PPA. Class specificity was evaluated by testing ten IgG-positive and IgM-negative patient samples. Within-run precision (repeatability) was evaluated by testing negative sample and positive sample in 20 replicates. Between-run precision was evaluated by testing negative sample and positive sample on five separate runs with two replicates per run. For interference testing, hemoglobin (200 mg/dL), bilirubin (2 mg/dL), triglyceride $(250 \mathrm{mg} / \mathrm{dL})$ and EDTA $(10 \mathrm{mM})$ were spiked into serum samples, respectively, and the MFI was compared with the control samples.

\subsection{Statistical Analysis}

For precision evaluations, coefficient of variation $(\mathrm{CV})$ was calculated as the ratio of the standard deviation (SD) to the mean. For interference testing, the samples spiked with potential interfering substances were compared with the control samples by paired T-test with $\mathrm{p} \leq 0.05$ defined as significantly different.

\section{Results}

\subsection{Clinical Performance}

Forty two (42) serum samples collected at different times from individuals who tested positive with a RT-

PCR method for SARS-CoV-2 infection were used in the evaluation of positive percent agreement (PPA). One hundred and sixty two (162) serum or EDTA plasma samples collected from healthy donors were 
medRxiv preprint doi: https://doi.org/10.1101/2021.01.22.20249050; this version posted January 26, 2021. The copyright holder for this preprint (which was not certified by peer review) is the author/funder, who has granted medRxiv a license to display the preprint in perpetuity.

All rights reserved. No reuse allowed without permission.

used in the evaluation of Negative Percent Agreement (NPA). As shown in Table 1, PPA was 42.86\% (95\% CI: $9.90 \%$ to $81.59 \%$ ), $71.43 \%$ (95\% CI: $29.04 \%$ to $96.33 \%$ ), and $28.57 \%$ (95\% CI: $13.22 \%$ to $48.67 \%$ ) for samples collected on 0-7 days, 8-14 days, and 2-8 weeks from symptom onset, respectively, and NPA was $97.53 \%$ (95\% CI: $93.80 \%$ to $99.32 \%)$.

In addition, 4 pairs of matched serum and EDTA plasma samples (i.e. collected from the same COVID-19 patients) were tested with QuantiVirus ${ }^{\mathrm{TM}}$ Anti-SARS-CoV-2 IgM Test and 100\% concordance was observed (data not shown). It indicates that EDTA plasma is as acceptable as serum for this test.

\subsection{Interfering Substance}

Hemoglobin $(200 \mathrm{mg} / \mathrm{dL})$ was spiked into three serum samples to test the potential interfering effect of high-level hemoglobin which might be present in hemolysis and other conditions. Bilirubin ( $2 \mathrm{mg} / \mathrm{dL})$ was spiked into three serum samples to test the potential interfering effect of high-level bilirubin in the blood which might be caused by liver dysfunction such as hepatitis and cirrhosis. Triglyceride (250 $\mathrm{mg} / \mathrm{dL}$ ) was spiked into three serum samples to test the potential interfering effect of high triglyceride levels which are often a sign of conditions that increase the risk of heart disease and stroke, including obesity and metabolic syndrome. Lastly, EDTA (10mM) was spiked into three serum samples to test the potential interfering effect of EDTA which is the anticoagulant used in EDTA blood collection tubes. As shown in Table 2, the difference in the fluorescence signal (MFI) between the control samples and the samples spiked with hemoglobin, bilirubin, triglyceride or EDTA was all $\leq 15.0 \%$ which is acceptable to the test and no false negative or false positive results were observed.

\subsection{Precision}

Intra-assay reproducibility (repeatability) was evaluated by testing negative sample and positive sample in 20 replicates and the $\mathrm{CV} \%$ of MFI was calculated. Inter-assay reproducibility (between-run precision) was evaluated by testing negative sample and positive sample on five separate runs and the CV\% of the 
medRxiv preprint doi: https://doi.org/10.1101/2021.01.22.20249050; this version posted January 26, 2021. The copyright holder for this preprint (which was not certified by peer review) is the author/funder, who has granted medRxiv a license to display the preprint in perpetuity.

All rights reserved. No reuse allowed without permission.

Ratio of MFI Sample to MFI Blank was calculated. As shown in Table 3 and Table 4, the CV\% of within-run precision and between-run precision was below $15.0 \%$ and $20.0 \%$, respectively.

\subsection{Class Specificity}

Antibody class specificity between IgM and IgG was tested for cross reactivity. Ten SARS-CoV-2 patient samples which were positive for IgG and negative for IgM (tested by DIAZYME SARS-CoV-2 IgG and IgM CLIA kit) were tested with QuantiVirus ${ }^{\mathrm{TM}}$ anti-SARS-CoV-2 IgM test and all were negative, thus establishing the specificity of the QuantiVirus ${ }^{\mathrm{TM}}$ anti-SARS-CoV-2 IgM test to the IgM class of antibodies (Table 5).

\section{Discussion}

Antibody tests are blood tests that detect antibodies or immunoglobulins that are produced as the human immune response to SARS-CoV-2 infection. Antibody testing has multiple essential roles: it can identify asymptomatic infections, verify that vaccines are working, be used in contact tracing after a suspected infection in an individual, and to help inform public policy makers how many asymptomatic cases have occurred in a population (6-8). As of October 28, 2020, more than 50 serological tests have been approved by FDA for emergency use authorization (EUA) for the detection of anti-SARS-CoV-2 IgM, $\mathrm{IgG}$, or total antibodies and in various formats including lateral flow immunoassays (LFAs), enzymelinked immunosorbent assays (ELISAs), chemiluminescent immunoassays (CLIA), and beads-based fluorescent immunoassays (9).

Despite the enormous efforts put by companies and researchers into developing serological assays, diagnostic accuracy of serological tests for COVID-19 has been largely variable. Bastos et al performed a systematic review and meta-analysis of published data on Medline, bioRxiv, and medRxiv from 1 January to 30 April 2020, and found that the pooled sensitivity of ELISAs measuring $\operatorname{IgG}$ or $\operatorname{IgM}$ was $84.3 \%$ (95\% confidence interval $75.6 \%$ to $90.9 \%$ ), of LFIAs was $66.0 \%$ (49.3\% to $79.3 \%$ ), and of CLIAs was $97.8 \%$ (46.2\% to $100 \%)(10)$. Furthermore, sensitivity was higher at least three weeks after symptom onset 
medRxiv preprint doi: https://doi.org/10.1101/2021.01.22.20249050; this version posted January 26, 2021. The copyright holder for this preprint (which was not certified by peer review) is the author/funder, who has granted medRxiv a license to display the preprint in perpetuity.

All rights reserved. No reuse allowed without permission.

(ranging from $69.9 \%$ to $98.9 \%$ ) compared with within the first week (from 13.4\% to 50.3\%). Similar findings have been confirmed by other investigators as well $(11,12)$.

Of note, multiple publications have indicated that the appearance of detectable anti-SARS-CoV-2 IgM antibodies after infection with COVID-19 is delayed, resulting in abnormal sensitivity in the early days after the onset of symptoms. For instance, a group from Germany observed that less than $50 \%$ of patients produced detectable anti-SARS-COV-2 IgM in the first 10 to 14 days after the "onset" of symptoms (13). Similarly, Long et al showed that only $12 \%$ to $40 \%$ of patients developed anti-SARS-COV-2 IgM seroconversion during 1 to 7 days post onset of symptom (14). Using an ELISA designed to detect antiSARS-COV-2 IgM antibodies against the RBD of the S1 subunit, data from Zhao et al. showed that approximately $28 \%$ of patients were $\operatorname{IgM}$ positive by day 7 whereas $73 \%$ turned positive by day 14 post symptom onset (15). In agreement with those previous findings, using the QuantiVirus ${ }^{\mathrm{TM}}$ anti- SARSCoV-2 IgM Test developed in our lab, we found that $42.86 \%$ of patients produced detectable IgM antibody in the first 7 days post symptom onset and increased to $71.43 \%$ by day 14 . The test indicated a leading accuracy of report for the patient samples in the first 7 days, and a reliable report rate as the time extended.

To further establish the assay accuracy, and consistency against various patient conditions, we also showed that this microsphere -based fluorescence immunoassay has a high specificity of $97.53 \%$ and is compatible with both serum and EDTA-plasma samples. The interference of substances, such as hemoglobin, bilirubin and triglyceride, would not generate inaccurate results. This indicates the potential application of our test on patients with certain health conditions.

QuantiVirus $^{\mathrm{TM}}$ anti- SARS-CoV-2 IgM Test also demonstrated an excellent reproducibility, where the intra-assay variations are lower than $15 \%$ for positive samples, and $6.4 \%$ for the negative serum sample. The variations are below $20 \%$ when it comes to the comparison of readings among 5 different test runs. Therefore, QuantiVirus ${ }^{\mathrm{TM}}$ anti-SARS-CoV-2 IgM Test provides reliable, reproducible results for patient screening, confirmation, and tracing. 
medRxiv preprint doi: https://doi.org/10.1101/2021.01.22.20249050; this version posted January 26, 2021. The copyright holder for this preprint (which was not certified by peer review) is the author/funder, who has granted medRxiv a license to display the preprint in perpetuity.

All rights reserved. No reuse allowed without permission.

In addition, QuantiVirus ${ }^{\mathrm{TM}}$ anti- SARS-CoV-2 IgM Test provides a simplified workflow for clinical practices (Figure 1). The pre-coupled capture beads and reporting complex reduced the time-consuming operations of RBD binding. Reducing the workflow could further reduce the operational error introduced from RBD protein conjugation. The workflow can be quickly adapted by clinical practices to improve the throughput and can be easily integrated into a laboratory's clinical operations.

In conclusion, we have successfully developed a reliable high-throughput microsphere immunoassay for qualitative detection of anti-SARS-CoV-2 IgM antibody. The assay was validated with COVID19

positive samples as well as negative samples obtained from healthy donors on MAGPIX ${ }^{\circledR}$ instrument. We believe that this assay will help to determine the infection status of COVID-19 and the true scope of the pandemic.

\section{Author contributions}

D. Zhang, J. Du, T. Xu and E. Chu conducted the experiments. J. Du, D. Zhang and M. Sha wrote the draft of the manuscript. M. Sha and A. Zhang reviewed and edited the manuscript. All the authors read and approved the final manuscript.

\section{Declaration of competing interest}

Dayu Zhang, Tianyang Xu, Eric Chu, Aiguo Zhang, Jinwei Du and Michael Y. Sha are employees of DiaCarta Inc.

\section{References}

1. Zhu, N. et al. A Novel Coronavirus from Patients with Pneumonia in China, 2019. $N$ Engl J Med. 382, 727-733 (2020).

2. Holshue, M. et al. First Case of 2019 Novel Coronavirus in the United States. N Engl J Med. 382, 929-936 (2020). 
medRxiv preprint doi: https://doi.org/10.1101/2021.01.22.20249050; this version posted January 26, 2021. The copyright holder for this preprint (which was not certified by peer review) is the author/funder, who has granted medRxiv a license to display the preprint in perpetuity.

All rights reserved. No reuse allowed without permission.

3. Loeffelholz, M. \& Tang, Y.W. Laboratory diagnosis of emerging human coronavirus infections - the state of the art. Emerg Microbes Infect. 9, 747-756 (2020).

4. Long, Q.X. et al. Antibody responses to SARS-CoV-2 in patients with COVID-19. Nat Med. 26, 845-848 (2020)

5. Patel, R. et al. Report from the American Society for Microbiology COVID-19 International Summit, 23 March 2020: Value of Diagnostic Testing for SARS-CoV-2/COVID-19. MBio. 11, e00722-20 (2020)

6. Mathur, G. \& Mathur, S. Antibody Testing for COVID-19. Am J Clin Pathol. 154, 1-3 (2020)

7. Theel, ES. et al. The Role of Antibody Testing for SARS-CoV-2: Is There One? J Clin Microbiol. 58, e00797-20 (2020)

8. Petherick, A. Developing antibody tests for SARS-CoV-2. Lancet. 395, 1101-1102 (2020)

9. https://www.fda.gov/emergency-preparedness-and-response/mcm-legal-regulatory-and-policyframework/emergency-use-authorization\#covidinvitrodev

10. Bastos, M.L. et al. Diagnostic accuracy of serological tests for covid-19: systematic review and meta-analysis. BMJ. 370, m2516(2020)

11. Kontou, PI. et al. Antibody Tests in Detecting SARS-CoV-2 Infection: A Meta-Analysis. Diagnostics (Basel). 10, 319 (2020)

12. Wang, H. et al. Meta-analysis of diagnostic performance of serology tests for COVID-19: impact of assay design and post-symptom-onset intervals. Emerg Microbes Infect. 9, 2200-2211 (2020)

13. Wölfel, R. et al. Virological assessment of hospitalized patients with COVID-2019. Nature, 581, $465-469(2020)$

14. Long, Q.X. et al. Antibody responses to SARS-CoV-2 in COVID-19 patients: the perspective application of serological tests in clinical practice. MedRxiv https://doi.org/10.1101/2020.03 .18.20038018 (2020) 
medRxiv preprint doi: https://doi.org/10.1101/2021.01.22.20249050; this version posted January 26, 2021. The copyright holder for this preprint (which was not certified by peer review) is the author/funder, who has granted medRxiv a license to display the preprint in perpetuity.

All rights reserved. No reuse allowed without permission.

15. Zhao, J. et al. Antibody responses to SARS-CoV-2 in patients of novel coronavirus disease 2019. Clin Infect Dis. 71, 2027-2034 (2020)
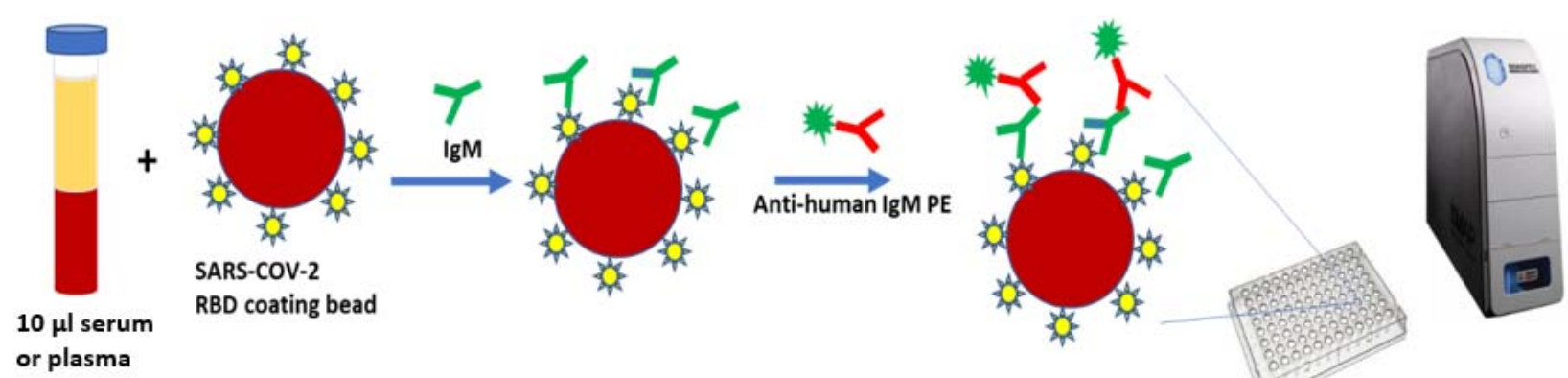

\section{Plate Setup}

Sample Incubation and Washing

Data Acquisition

30 minutes

$2 \sim 2.5$ hours

$45 \sim 60$ minutes

Figure 1. The high throughput Immunoassay for anti-SARS-CoV-2 IgM Detection

Table 1. Positive Percent Agreement (PPA) and Negative Percent Agreement (NPA)

\begin{tabular}{lccccl}
\hline Category & $\begin{array}{l}\text { Days from } \\
\text { Symptom Onset }\end{array}$ & $\begin{array}{l}\text { Number of } \\
\text { Samples }\end{array}$ & $\begin{array}{l}\text { IgG } \\
\text { Positive }\end{array}$ & $\begin{array}{l}\text { IgG } \\
\text { Negative }\end{array}$ & PPA and NPA (95\% CI) \\
\hline $\begin{array}{l}\text { COVID-19 } \\
\text { Positive }\end{array}$ & $0-7$ days & 7 & 3 & 4 & PPA: $42.86 \%(9.90 \%$ to $81.59 \%)$ \\
& $8-14$ days & 7 & 5 & 2 & PPA: $71.43 \%(29.04 \%$ to $96.33 \%)$ \\
$\begin{array}{l}\text { COVID-19 } \\
\text { Negative }\end{array}$ & n-8 weeks & 28 & 8 & 20 & PPA: $28.57 \%(13.22 \%$ to $48.67 \%)$ \\
\hline
\end{tabular}

n/a: not applicable

Table 2. Interfering substance testing

\begin{tabular}{|c|c|c|c|c|c|}
\hline Sample & Group & MFI-1 & MFI-2 & Avg & $\begin{array}{l}\text { Difference between } \\
\text { control and tested } \\
\text { substance }\end{array}$ \\
\hline \multirow{3}{*}{ Positive Sample \#1 } & Control & 888 & 837 & 863 & \\
\hline & EDTA & 875 & 841 & 858 & $-0.6 \%$ \\
\hline & Hemoglobin & 722 & 800 & 761 & $-11.8 \%$ \\
\hline
\end{tabular}


medRxiv preprint doi: https://doi.org/10.1101/2021.01.22.20249050; this version posted January 26, 2021. The copyright holder for this preprint (which was not certified by peer review) is the author/funder, who has granted medRxiv a license to display the preprint in perpetuity. All rights reserved. No reuse allowed without permission.

\begin{tabular}{|c|c|c|c|c|c|}
\hline \multirow{3}{*}{ Positive Sample \#2 } & Control & 1340 & 1378 & 1359 & \\
\hline & EDTA & 1318 & 1276 & 1297 & $-4.6 \%$ \\
\hline & Hemoglobin & 1220 & 1155 & 1188 & $-12.6 \%$ \\
\hline \multirow{3}{*}{ Negative sample } & Control & 64 & 68 & 66 & \\
\hline & EDTA & 59 & 54 & 57 & $-13.6 \%$ \\
\hline & Hemoglobin & 55 & 59 & 57 & $-13.6 \%$ \\
\hline \multirow{2}{*}{ Positive Sample \#1 } & Control & 793 & 769 & 781 & \\
\hline & Bilirubin & 779 & 867 & 823 & $5.4 \%$ \\
\hline \multirow{2}{*}{ Positive Sample \#2 } & Control & 1041 & 1240 & 1140 & \\
\hline & Bilirubin & 985 & 1186 & 1085 & $-4.8 \%$ \\
\hline \multirow{2}{*}{ Negative sample } & Control & 47 & 48 & 47 & \\
\hline & Bilirubin & 45 & 49 & 47 & $-0.5 \%$ \\
\hline \multirow{2}{*}{ Positive Sample \#1 } & Control & 682 & 696 & 689 & \\
\hline & Triglyceride & 670 & 745 & 708 & $2.7 \%$ \\
\hline \multirow{2}{*}{ Positive Sample \#2 } & Control & 1209 & 1099 & 1154 & \\
\hline & Triglyceride & 1166 & 1107 & 1137 & $-1.5 \%$ \\
\hline \multirow{2}{*}{ Negative sample } & Control & 54 & 49 & 52 & \\
\hline & Triglyceride & 47 & 47 & 47 & $-8.7 \%$ \\
\hline
\end{tabular}

Table 3. Intra-assay reproducibility

\begin{tabular}{|c|c|c|c|c|c|c|c|c|c|c|c|c|c|}
\hline Sample & \multicolumn{10}{|c|}{ MFI of each of 20 replicates } & Avg & SD & CV\% \\
\hline \multirow{2}{*}{ Serum\#36 } & 1717 & 1147 & 1210 & 1404 & 1391 & 1263 & 1361 & 1655 & 1674 & 1494 & \multirow{2}{*}{1394} & \multirow{2}{*}{189} & \multirow{2}{*}{$13.5 \%$} \\
\hline & 1412 & 1285 & 1348 & 1550 & 1500 & 1437 & 1618 & 1196 & 1077 & 1146 & & & \\
\hline \multirow{2}{*}{ Serum\#32 } & 985 & 1295 & 988 & 1020 & 1172 & 1045 & 1060 & 973 & 721 & 887 & \multirow{2}{*}{1024} & \multirow{2}{*}{148} & \multirow{2}{*}{$14.4 \%$} \\
\hline & 929 & 769 & 869 & 1170 & 1083 & 1212 & 1198 & 1093 & 1072 & 943 & & & \\
\hline \multirow{2}{*}{ Serum_N } & 40 & 43 & 41 & 41 & 42 & 40 & 46 & 42 & 41 & 44 & \multirow{2}{*}{42} & \multirow{2}{*}{3} & \multirow{2}{*}{$6.4 \%$} \\
\hline & 39 & 43 & 43 & 41 & 44 & 39 & 35 & 38 & 43 & 46 & & & \\
\hline
\end{tabular}

Table 4. Inter-assay reproducibility

\begin{tabular}{|l|r|r|r|r|r|r|r|r|}
\hline Sample & \multicolumn{1}{|c|}{ Test-1 } & \multicolumn{1}{l|}{ Test-2 } & \multicolumn{1}{l|}{ Test-3 } & \multicolumn{1}{l|}{ Test-4 } & \multicolumn{1}{l|}{ Test-5 } & Avg & \multicolumn{1}{l|}{ SD } & \multicolumn{1}{l|}{ CV\% } \\
\hline Serum\#36 & 99.7 & 106.5 & 84.9 & 74.0 & 98.3 & 92.7 & 13.03 & $14.1 \%$ \\
\hline Serum\#32 & 72.9 & 48.1 & 53.9 & 46.8 & 53.6 & 55.1 & 10.47 & $19.0 \%$ \\
\hline Serum_N & 3.0 & 3.6 & 4.1 & 3.2 & 3.1 & 3.4 & 0.48 & $14.1 \%$ \\
\hline
\end{tabular}


medRxiv preprint doi: https://doi.org/10.1101/2021.01.22.20249050; this version posted January 26, 2021. The copyright holder for this preprint (which was not certified by peer review) is the author/funder, who has granted medRxiv a license to display the preprint in perpetuity.

All rights reserved. No reuse allowed without permission.

Table 5. Class-specificity test

\begin{tabular}{|c|c|c|c|c|c|}
\hline \multirow{2}{*}{ Sample } & \multicolumn{2}{|c|}{$\begin{array}{l}\text { DIAZYME SARS-CoV-2 IgG/IgM } \\
\text { CLIA kit }\end{array}$} & \multicolumn{3}{|c|}{ QuantiVirus $^{\mathrm{TM}}$ anti-SARS-CoV-2 IgM test } \\
\hline & $\begin{array}{l}\text { SARS-CoV-2 } \\
\text { IgG }\end{array}$ & $\begin{array}{l}\text { SARS-CoV-2 } \\
\text { IgM }\end{array}$ & MFI & Ratio of MFI Sample to $_{\text {MFI }}$ Blank & Interpretation \\
\hline ProMed\#p21 & positive & $<1$ & 67 & 4 & negative \\
\hline ProMed\#p22 & positive & $<1$ & 189 & 11 & negative \\
\hline ProMed\#p23 & positive & $<1$ & 85 & 5 & negative \\
\hline ProMed\#p24 & positive & $<1$ & 86 & 5 & negative \\
\hline ProMed\#p25 & positive & $<1$ & 333 & 20 & negative \\
\hline ProMed\#p26 & positive & $<1$ & 445 & 26 & negative \\
\hline ProMed\#p27 & positive & $<1$ & 228 & 13 & negative \\
\hline ProMed\#p28 & positive & $<1$ & 154 & 9 & negative \\
\hline ProMed\#p31 & positive & $<1$ & 185 & 11 & negative \\
\hline ProMed\#p32 & positive & $<1$ & 316 & 19 & negative \\
\hline
\end{tabular}

